\title{
Nomenclatural revision of Delphinium subg. Consolida (DC.) Huth (Ranunculaceae)
}

\author{
Pierre-Emmanuel DuPasquier ${ }^{1,2}$, Véronique Andro-Durand ${ }^{3}$, \\ Lucas Batory', Wei Wang ${ }^{4,5}$, Florian Jabbour'
}

I Institut Systématique Evolution Biodiversité (ISYEB), Muséum national d'Histoire naturelle, CNRS, Sorbonne Université, EPHE, Université des Antilles, 57 rue Cuvier, CP39, 75005 Paris, France 2 Université de Neuchâtel, espace Tilo-Frey 1, 2000 Neuchâtel, Switzerland 3 Direction des Collections Naturalistes - Botanique, Muséum national d'Histoire naturelle, 57 rue Cuvier, CP39, 75005 Paris, France 4 State Key Laboratory of Systematic and Evolutionary Botany, Institute of Botany, Chinese Academy of Sciences, Beijing 100093, China 5 University of Chinese Academy of Sciences, Beijing 100049, China

Corresponding author: Pierre-Emmanuel DuPasquier (pierre-emmanuel.dupasquier@unine.ch)

Academic editor: M. Pellegrini | Received 16 April 2021 | Accepted 1 July 2021 | Published 5 August 2021

Citation: DuPasquier P-E, Andro-Durand V, Batory L, Wang W, Jabbour F (2021) Nomenclatural revision of Delphinium subg. Consolida (DC.) Huth (Ranunculaceae). PhytoKeys 180: 81-110. https://doi.org/10.3897/ phytokeys. 180.67126

\begin{abstract}
Recent molecular phylogenetic studies have indicated that Aconitella is embedded in Consolida, which in turn is embedded in Delphinium. We choose not to split the genus Delphinium (c. 300 species), as it is horticulturally and pharmaceutically important, by conserving a broad Delphinium by transferring the names from Consolida and Aconitella to Delphinium s.lat., and more precisely in the resurrected D. subg. Consolida. Including 58 species of Aconitella and Consolida within Delphinium causes fewer nomenclatural overall changes than do alternative schemes because most of the species of Aconitella and Consolida were once named under the name Delphinium. We present here the list of synonyms for the species once named under Consolida or Aconitella and gather the information relative to the types of these names. Two new combinations are provided, and 21 lectotypes are designated here.
\end{abstract}

\section{Keywords}

Aconitella, larkspur, Old World flora, paraphyly, Ranunculales

Copyright Pierre-Emmanuel DuPasquier et al. This is an open access article distributed under the terms of the Creative Commons Attribution License (CC BY 4.0), which permits unrestricted use, distribution, and reproduction in any medium, provided the original author and source are credited. 


\section{Introduction}

Different taxonomic systems based on morphological characters have led authors to treat Consolida J.F.Gray (including Aconitella Spach) (Fig. 1) and Delphinium L. (Ranunculaceae) as two different genera (Linnaeus 1753; Soó 1922; Davis 1965; Munz 1967a, b; Greuter and Long 1989; Chater 1993; Tamura 1993), or to consider Consolida as included in Delphinium (Candolle 1824; Boissier 1867; Huth 1895; Chowdhuri et al. 1958).

Based on a molecular phylogenetic study with a broad taxonomic sampling, Jabbour and Renner (2011) first found that Consolida and Aconitella were embedded in Delphinium. More precisely, Aconitella was nested within Consolida, which in turn was nested within Delphinium. More recent analyses confirmed this result (Jabbour and Renner 2012a; Wang et al. 2013; Xiang et al. 2017) but do not support the different subgroups (the "Untergruppen or Tribus") previously described in Consolida (Huth 1895). Thus, the overemphasis on distinctive characters (see Pfeil and Crisp 2005) in Consolida and Aconitella led to recognizing a paraphyletic Delphinium.
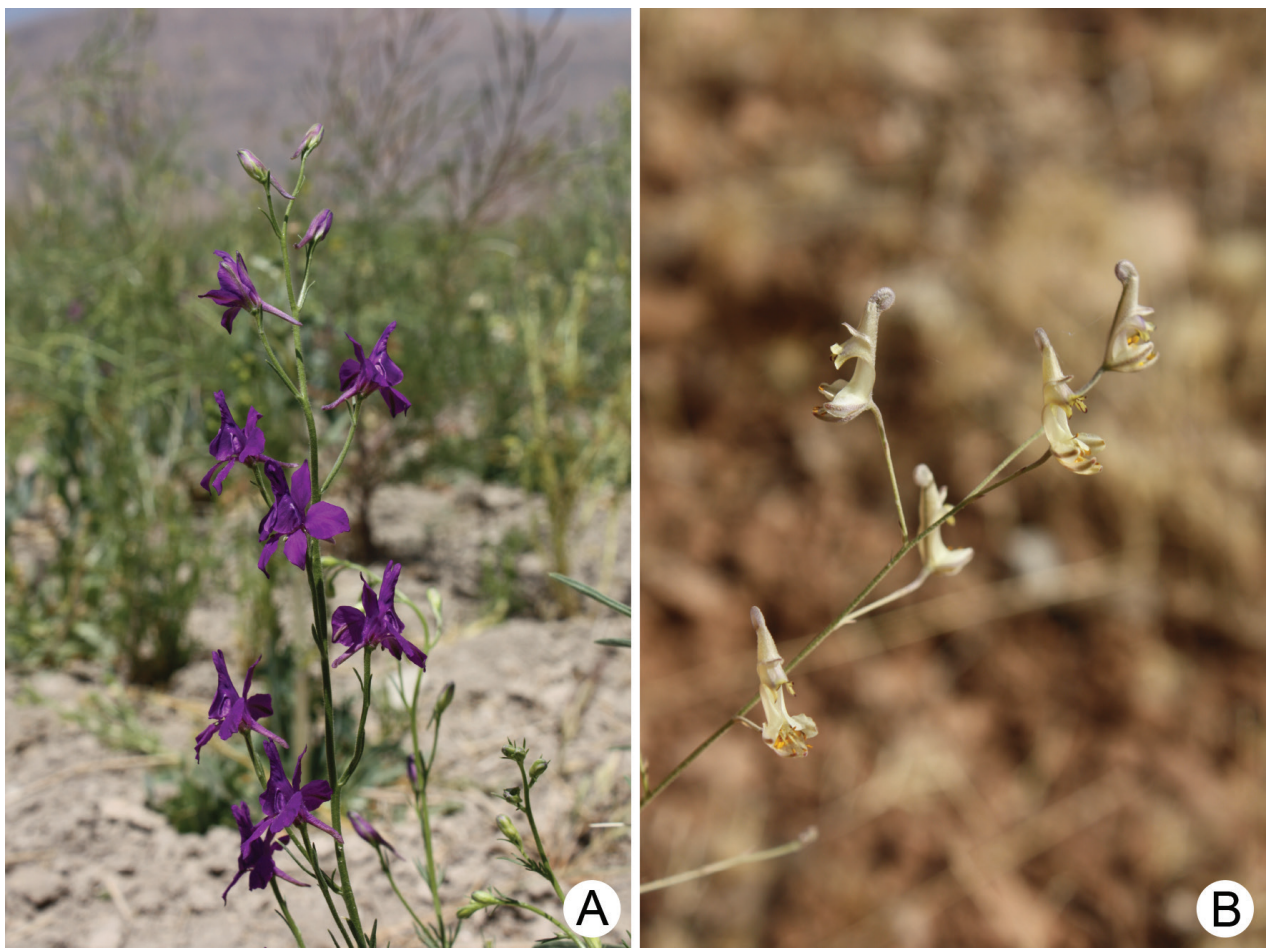

Figure I. Inflorescences of Delphinium subg. Consolida A Delphinium hispanicum Costa B D. anthoroideum Boiss. Photos: Shahin Zarre (Iran, 2011). 
As a consequence of these results, the last author previously decided (Christenhusz et al. 2018: 73) not to split the large genus Delphinium (c. 300 species), as it is horticulturally and pharmaceutically important (Tamura 1993), by conserving a broad Delphinium (see Kadereit et al. 2016) by transferring under Delphinium the eight species names (out of 58) of Consolida, all published after 1965, that were never transferred. The new combinations were: $D$. arenarium (Carlström) Jabbour, D. coelesyriacum (Mouterde) Jabbour, D. kandaharicum (Iranshahr) Jabbour, D. lineolatum (Hub.-Mor. \& C.Simon) Jabbour, D. lorestanicum (Iranshahr) Jabbour, D. samium (P.H.Davis) Jabbour, D. staminosum (P.H.Davis \& Sorger) Jabbour, and D. stapfianum (P.H.Davis \& Sorger) Jabbour.

As flower morphological characters support a clade including Consolida and Aconitella (Jabbour and Renner 2012b), we treat Consolida as a subgenus of Delphinium in this article. We re-introduce here Delphinium subg. Consolida (DC.) Huth and list its 58 species with information relative to their typification.

\section{Methods}

We analysed the original material cited in the protologue of each taxon and compiled the relevant synonyms. Except for rare cases, the infraspecific taxa of Consolida are not mentioned as taking taxonomic decisions at this taxonomic level is beyond the scope of this work.

Herbarium specimens and images of specimens from the herbaria ATHU, B, BASBG, BC, BEI, BH, BM, BP, BR, C, E, FI, FR, G, GB, GH, GOET, GZU, H, HAL, HBG, HUJ, ISL, JE, K, L, LD, LE, LI, LY, MJSD, MA, MEL, MO, NY, O, OXF, P, PAD, PH, S, TARI, UC, UPS, US, W, WAG, WRSL, and WU were examined. We studied all the available digitized specimens of the relevant collections. The following online resources were consulted: Geneva Herbaria Catalogue, JSTOR Global Plants, Kew Herbarium Catalogue, Naturalis BioPortal, Paris virtual herbarium of vascular plants, RBGE Herbarium Catalogue, Sweden's Virtual Herbarium, the University and Jepson Herbaria, the Virtual Herbaria JACQ, and the Virtual herbarium Berolinense.

Based on the methodology of typification followed by Al-Shehbaz and Barriera (2019), we provide notes about the typification, especially if a lectotype is designated here for the first time or if earlier lectotypifications were incomplete or erroneous. In some cases and some relatively recently described species, the holotype was not found in the mentioned herbarium. When we consider that further investigations are necessary, we have decided not to designate a lectotype. Accepted names are in bold italics and listed alphabetically. The reference of cited specimens (herbarium code, and when available, the barcode) are provided. The herbarium codes follow Thiers (2018). Specimens marked '? were examined in the scope of this paper. Note that JE, WU, and W barcodes have temporary barcodes and are susceptible to change in the future (Jochen Müller, Dieter Reich, and Christian Braüchler, curators, pers. comm.). 


\section{Results}

Delphinium subg. Consolida consists of 58 species. Two new combinations are made, and 21 lectotypes (including three second-step lectotypifications) are designated herein.

\section{Typification and nomenclature}

Delphinium subg. Consolida (DC.) Huth, Bot. Jahrb. 20: 337. 1895.

三 Consolida S.F.Gray, Nat. Arr. Brit. Pl. 2: 711. 1821.

$\equiv$ Delphinium sect. Consolida DC., Reg. Veg. Syst. Nat. 1: 341. 1817.

三 Ceratosanthus Schur, Enum. Pl. Transsilv. 30. 1866. Type: Delphinium consolida L.

= Delphinium subg. Aconitella (Spach) Iranshahr, Fl. Iranica 171: 92. 1992.

E Aconitella Spach in Hist. Nat. Veg. 7: 358. 1839.

三 Consolida sect. Aconitella (Spach) Tamura in Acta Phytotax. Geobot. 41: 101. 1990.

Type: Delphinium aconiti L.

$=$ Aconitopsis Kem.-Nath. in Trudy Tbilissk. Bot. Inst. 7: 125. 1940. Type: not designated.

\section{Delphinium aconiti L., Mant. P1.: 77. 1767 [basionym].}

E Consolida aconiti (L.) Lindley in J. Roy. Hort. Soc. 6: 55. 1851.

三 Aconitella aconiti (L.) Soják in Folia Geobot. Phytotax. Bohem. 4: 448. 1969.

$\equiv$ Aconitopsis aconiti (L.) Kem.-Nath. in Trudy Tbilissk. Bot. Inst. 7: 125. 1940, non Aconitella delphinioides Spach in Hist. Nat. Veg. 7: 359. 1839.

三 Aconitum monogynum Forssk., Fl. Aegypt.-Arab. 27. 1775. Type: Turkey. “ in Dardanella”, leg. P. Forsskål (holotype not found).

Notes. The description of D. aconiti is based on a Forsskål's gathering made "in Dardanella". At LINN, no Forsskål's material was found for this taxon, whereas two gatherings, Forsskål 913 (C10001572) and Forsskal 914 (C10001573), are deposited at C, in the Vahl herbarium, and are likely to correspond to the type material. The typification of the Forsskål collection is complex and needs a careful examination of the letters sent by Forsskål to Linnaeus. Note that Forsskal 914 was a priori used for the tab XIII (Vahl 1790).

\section{Delphinium ajacis L., Sp. P1.: 531.1753 [basionym].}

三 Consolida ajacis (L.) Schur in Verh. Mitth. Siebenbürg. Vereins Naturwiss. Hermannstadt 4: 47. 1853.

$\equiv$ Ceratosanthus ajacis (L.) Schur in Enum. Pl. Transsilv. 30. 1866. Type: Herb. Burser VII(1): 83 (lectotype, designated by Molero and Blanché 1984, pg. 217: UPS image!). 
= Delphinium gayanum Wilmott in J. Bot. 62: 26. 1924.

三 Consolida gayana (Wilmott) Laínz, in Anales Inst. Forest. Invest. 1967: 6. 1967.

- Consolida ambigua auct. non Delphinium ambiguum L.

Notes. Consolida ambigua auct. (non D. ambiguum L.) is a misapplied name of D. ajacis in most floras, such as "Flora Europaea" (Chater 1993) and "Flora of Turkey and the East Aegean Islands" (Davis 1965). For details, see Janchen (1965: 34).

3. Delphinium anthoroideum Boiss. in Ann. Sci. Nat. Bot. Ser. 2, 16: 369. 1841 [basionym], non sensu Boiss., Fl. Or. 1: 85. 1867.

E Consolida anthoroidea (Boiss.) Schrödinger in Abh. K. K. Zool.-Bot. Ges. Wien 4(5): 62. 1909.

EAconitella anthoroidea (Boiss.) Soják in Folia Geobot. Phytotax. Bohem. 4: 448. 1969.

E Aconitopsis anthoroidea Kem.-Nath. in Trudy Tbilissk. Bot. Inst. 7: 125. 1940. Type: "Syria", s.d., leg. P. M. R. Aucher-Eloy 65 (lectotype, designated by Chowdhuri et al. 1958, pg. 412: G-BOIS [G00788330 image!, 2 sheets]; isolectotypes: $\mathrm{E}$ [E00438703 image! =photo of G00788330], G [G00390151 image!], K [K000692355 image!], P [P00195789!, P00195790!].

= Delphinium acutilobum Turrill in Bull. Misc. Inform. Kew 1929: 223. 1929. Type: Azerbaïdjan. "near Tabriz. Yam.", 21 Aug. 1927, leg. B. Gilliat-Smith 2086 (holotype: K [K000692358 image!]).

Notes. The misinterpretation of $D$. anthoroideum by Boissier in "Flora Orientalis" (1867) is clarified by Chowdhuri et al. (1958). Among the isolectotypes of $D$. anthoroideum, only G00390151 and P00195789 bear the date "1837".

4. Delphinium arenarium (A.Carlström) Jabbour in Global Fl. 4(1): 73. 2018.

E Consolida arenaria A.Carlström in Willdenowia 14: 16. 1984 [basionym]. Type: Greece. South Aegean: "Rodos. $2 \mathrm{~km}$ E of Archipolis, Stegena beach", 13 May 1982, leg. A. Carlström 5808 (holotype: LD [LD1023446 image!]).

Notes. No duplicate of the type collection was found.

\section{Delphinium armeniacum Huth in Bot. Jahrb. Syst. 20: 380.1895 [basionym].}

三 Consolida armeniaca (Huth) Schrödinger in Abh. K. K. Zool.-Bot. Ges. Wien 4(5): 62. 1909.Type: Turkey. Erzincan: “Sipikordagh”, 30 Jul. 1890, leg. P. E. E. Sintenis 
3177 (lectotype, designated here: WU [WU 109667 image!]; isolectotypes: BR [BR0000005295548 image!], G [G00390154 image!], GZU [GZU000278000 image!], JE [JE00018622 image!, JE00018623 image!], K [K000692372 image!, K000692373 image!], LD [LD1742274 image!], LE [LE01053086 image!], P [P00195865!] (Fig. 2A), PH [PH00010711 image!], WRSL [destroyed during the WWII]).

Notes. Chowdhuri et al. (1958) indicated the holotype at W, but we were unable to find it. No duplicate from the above herbaria was annotated by Huth, and we choose to designate WU 109667 as the lectotype for now.

\section{Delphinium aucheri Boiss. in Ann. Sci. Nat. Bot. Ser. 2, 16: 362.1841 [basionym].}

三 Delphinium persicum Boiss. var. aucheri (Boiss.) Boiss., Fl. Orient. 1: 77. 1867.

三 Consolida aucheri (Boiss.) Iranshahr in Fl. Iranica 171: 103. 1992. Type. «Persia australis», s.d., leg. P. M. R. Aucher-Eloy 4030 (holotype: P [P00198500!]; isotypes: G [G00390155 image!], P [P00198911!]).

Notes. No specimen was found in Boissier's herbarium. Boissier's annotation on P00198500 indicates that the species description is based on that sheet, which is the holotype.

\section{Delphinium axilliflorum DC., Syst. Nat. 1: 341. 1817 [basionym].}

三 Consolida axilliflora (DC.) Schrödinger in Abh. K. K. Zool.-Bot. Ges. Wien 4: 62. 1909. Type: «Syrie», s.d., leg. J. J. Labillardière s.n. (holotype: FI [FI056536 image!]).

Notes. No duplicate of the type collection was found.

\section{Delphinium baluchistanicum (Qureschi \& Chaudhri) Jabbour \& Du Pasquier, comb. nov.}

urn:lsid:ipni.org:names:77218867-1

E Consolida baluchistanica Qureschi \& Chaudhri, Pakistan Syst. 2: 11.1978 [basionym]. Type: Pakistan. Baluchistan: "Water supply station", 23 Apr. 1977, leg. H. Mansoor \& A. Maqsood 394 (holotype: ISL).

Notes. When asking for an image of the holotype, the curator of ISL provided us only with an image of the specimen Mansoor \& Maqsood 395 (collected 23.04.1977), whereas the protologue indicates Mansoor \& Maqsood 394. We could not decide whether: 1) \#394 (the holotype) could not be found; or 2) \#395 is the holotype, and 

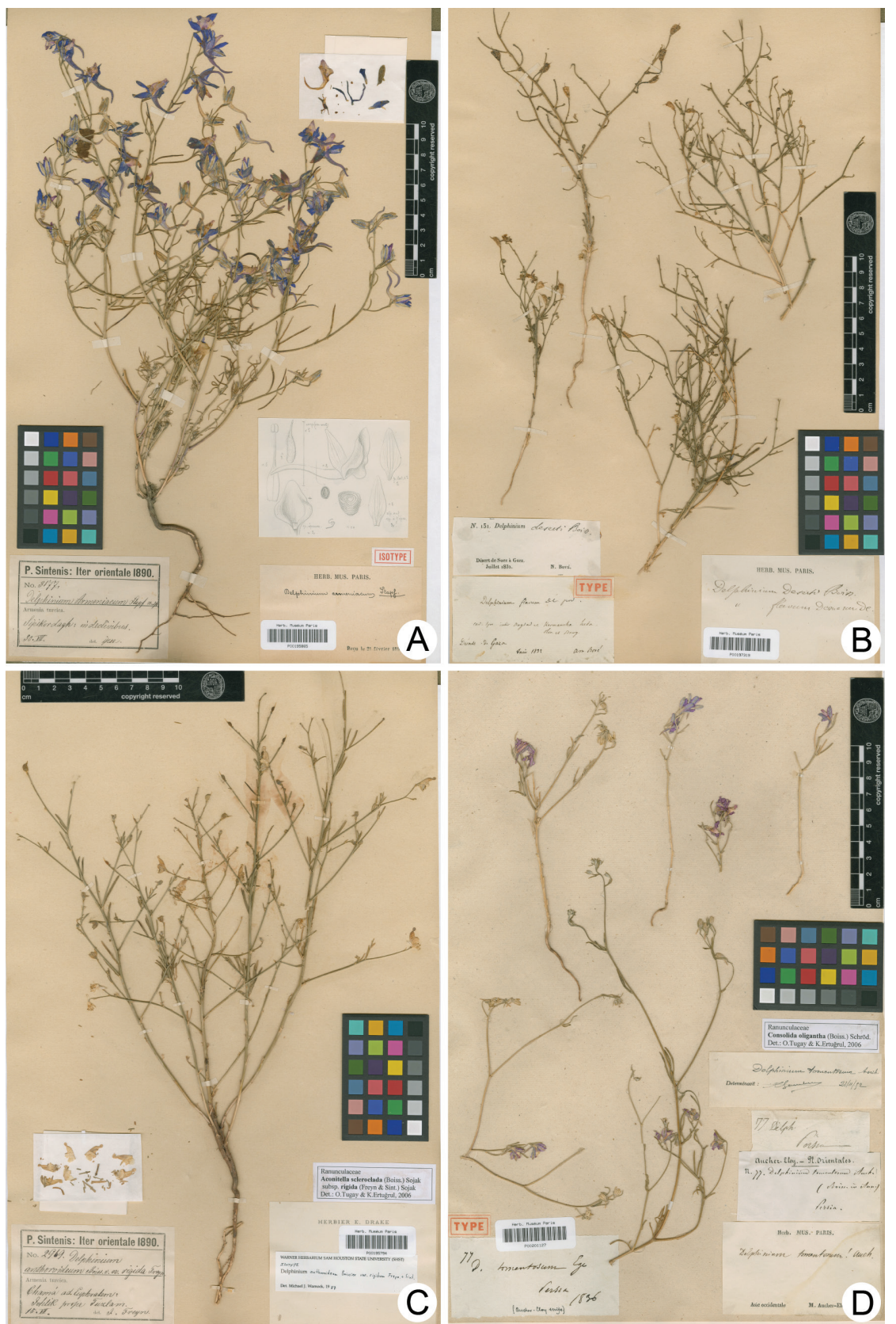

Figure 2. Three lectotypes (and one isolectotype) selected among the 21 lectotypes designated in this article $\mathbf{A}$ isolectotype of Delphinium armeniacum Huth (P00195865; http://coldb.mnhn.fr/catalognumber/ mnhn/p/p00195865) B lectotype of D. deserti Boiss. (P00197319; http://coldb.mnhn.fr/catalognumber/ mnhn/p/p00197319) C lectotype of Delphinium sclerocladum Boiss. var. rigidum (Freyn \& Sint.) Hossain \& P.H.Davis (P00195794; http://coldb.mnhn.fr/catalognumber/mnhn/p/p00195794) D lectotype of D. tomentosum Boiss. (P00201127; http://coldb.mnhn.fr/catalognumber/mnhn/p/p00201127). All four specimens are kept at $\mathrm{P}$ Herbarium. 
the \#394 citation in the protologue is a mistake. However, \#395 seems to have been used for the drawing on plate XI in Pakistan Syst. 2. (1978).

\section{Delphinium barbatum Bunge in Arb. Naturf. Ver. Riga 1: 126. 1847 [basionym].}

三 Consolida barbata (Bunge) Schrödinger in Abh. K. K. Zool.-Bot. Ges. Wien 4(5): 62. 1909.

E Aconitella barbata (Bunge) Soják in Folia Geobot. Phytotax. Bohem. 4: 448. 1969. 三 Aconitopsis barbata (Bunge) Kem.-Nath. in Trudy Tbilissk. Bot. Inst. 7: 127. 1940.

Type: Kazakhstan. "jugi Karatau, ad superiorem Sarafschan”, 10 Sep. 1841, leg. A. Lehmann 38 (lectotype, designated here: P [P00197235!]; isolectotypes: LE [LE00050813 image!, LE00050814 image!]).

Notes. Iranshahr (1992) indicated that the holotype is kept at P, whereas Munz (1967a) indicated that it is kept at LE, but without having seen it. We found a duplicate at $\mathrm{P}$ and two at LE. None of them seem to have been annotated by Bunge. The P00197235 sheet bears three specimens and two handwritten labels. These two labels are in Latin, probably from Lehmann's hand, and correspond to the locality indicated in the protologue. They are almost identical (the left one carries "Delphinium sp ?" and "10 Sept.", and the right one bears the collection year 1841 and no identification). Both labels were stuck on Bunge's printed handwritten labels "Reliquiae Lehmannianae. Herb. Al. de Bunge.", and the right one is itself stuck to another label ("Rel. Lehm. N ${ }^{\circ}$.38.") written by a different hand, probably a curator of P. At LE, the labels bear the exact mention of the locality as in the protologue (in German) on a preprinted label "Alexandri Lahmann/ Reliquiae botanicae. Al. Bunge." and one of both bears the full date.

10. Delphinium brevicorne Vis., Fl. Dalmat. 3: 90.1850 [basionym].

$\equiv$ Consolida brevicornis (Vis.) Soó in Österr. Bot. Z. 71: 245. 1922. Type. Croatia. Split-Dalmatia: "In agris circa Gelsa ins. Lesina/ as. Stalio", s.d., Stalio s.n. (holotype: PAD [image!]).

Notes. No duplicate of the type collection was found.

\section{Delphinium camptocarpum Ledeb., Fl. Ross. 1: 58. 1841 [basionym].}

E Consolida camptocarpa (Ledeb.) Nevski in Komarov, V. L., Fl. URSS 7: 106. 1937. Type: Irak. "Turcomania”, s.d., leg. G. S. Karelin, s.n. (Lectotype (first step 
designated by Nevski in Komarov, V. L., Fl. URSS 7: 106. 1937; second-step designated here): LE [LE00050875 image!]; isolectotypes: LE [LE00050877 image!, LE00050981 image!, LE00050986 image!).

Delphinium camptocarpum Ledeb. var. camptocarpum

三Delphinium campocarpum Ledeb. var. leiocarpum Ledeb., Fl. Ross. 1: 58. 1841.

Notes. When describing Delphinium camptocarpum, Ledebour quoted Karelin's gathering "ad latus orientale maris caspii" and described two varieties (D. camptocarpum var. dasycarpum and D. camptocarpum var. leiocarpum) according to the presence or not of indumentum on the follicle, but without citing any material. Several of Karelin's gatherings of $D$. camptocarpum were found at LE. Four of them belong to Ledebour's herbarium (two can be attributed to D. camptocarpum var. leiocarpum, but it is unclear for the other two) and can be regarded as type collection. We synonymise D. camptocarpum var. leiocarpum under the autonym.

Nevski's indication (1937) that the type is housed at LE can be considered a firststep lectotypification, and we designate here the specimen LE00050875 as the secondstep lectotype.

\section{Delphinium coelesyriacum (Mouterde) Jabbour in Global Fl. 4(1): 73. 2018.}

E Consolida coelesyriaca Mouterde, Nouv. Fl. Liban Syrie 2: 23. 1970 [basionym].

= Delphinium oliganthum auct. non Boiss.

= Consolida oligantha auct. non Boiss. Type: Syria. «entre Hama et Palmyre, Tell Bouada», 18 May 1857, leg. C. I. Blanche 2832 (holotype: G-BOIS [G00788352 image!]; isotype: $\mathrm{BEI}$ ?).

Notes. We did not find the duplicate at BEI, as could be expected from Mouterde's quotation (1970).

\section{Delphinium consolida L. Sp. Pl.: 530.1753 [basionym].}

E Consolida regalis S.F.Gray, Nat. Arr. Brit. Pl. 2: 711. 1821.

三 Ceratosanthus consolida (L.) Schur in Enum. Pl. Transsilv. 30. 1866.

$\equiv$ Consolida arvensis Opiz in Seznam 32. 1852. Type: Described from Britain. Herb. Linn. No. 694.1 (lectotype, designated by Jonsell and Jarvis 1994, pg. 161: LINN [LINN-HL694-1 image!]).

= Delphinium segetum Lam. Fl. Franç. 3: 325. 1778. [nom. illeg.]

- Consolida regalis S.F.Gray subsp. consolida (L.) Gajic in Josifovic, Fl. SR Srbije 1: 230. 1970. [nom. inval].

三 Consolida regalis S.F.Gray subsp. arvensis (Opiz) Soó, in Österr. Bot. Z. 71: 242. 1922. 
三 Delphinium consolida L. subsp. arvense (Opiz) Graebner \& Graebner fil., in Asch. \&

Graebn., Syn. Mitteleur. Fl. 5: 671. 1929. Type: not designated.

Notes. The genus Consolida published by Opiz (1852) is a valid but illegitimate name (Holub and Pouzar 1967).

Three subspecies are usually accepted under Delphinium consolida:

\subsection{Delphinium consolida L. subsp. consolida}

\subsection{Delphinium consolida L. subsp. paniculatum (Host) Busch in Kuznetzow, Fl. Cauc. Crit. 3: 44. 1902.}

三 Delphinium paniculatum Host, Fl. Austriaca 2: 65. 1831.

三 Consolida paniculata (Host) Schur. in Verh. Mitth. Siebenbürg. Vereins Naturwiss. Hermannstadt 4: 47. 1853.

$\equiv$ Consolida regalis S.F.Gray subsp. paniculata (Host) Soó in Österr. Bot. Z. 71: 243. 1922.

三 Ceratosanthus paniculata (Host) Schur in Enum. Pl. Transsilv. 30. 1866. Type: Montenegro. "near Cattaro", Tomasini s.n. (not found).

\subsection{Delphinium consolida L. subsp. divaricatum (Ledeb.) A.Nyár.}

三 Delphinium divaricatum Ledeb. in Eichw., Pl. Nov.: 16. 1831.

三 Consolida divaricata (Ledeb.) Schrödinger in Abh. K. K. Zool.-Bot. Ges. Wien 4(5): 27, 62. 1909.

$\equiv$ Consolida regalis S.F.Gray subsp. divaricata (Ledeb.) Munz in J. Arnold Arbor. 48: 179. 1967.

$\equiv$ Consolida regalis S.F.Gray subsp. paniculata (Host) Soó var. divaricata (Ledeb.) P.H.Davis in Notes Roy. Bot. Gard. Edinburgh 26: 174. 1965.

$\equiv$ Ceratosanthus divaricata (Ledeb.) Schur in Enum. Pl. Transsilv. 30. 1866. Type: Russia. "In insulis ad ostium Wolgae amnis sitis, etiam ad fluvium Torrain", Henning s.n. (holotype: LE [not seen]).

14. Delphinium cornutum Hossain \& P.H.Davis in Notes Roy. Bot. Gard. Edinburgh 22: 424.1958 [basionym].

三 Consolida cornuta (Hossain \& P.H.Davis) P.H.Davis in Notes Roy. Bot. Gard. Edinburgh 26: 174. 1965. Type: "Armenia", s.d., leg. Calvert \& Zohrab s.n. (holotype: $\mathrm{E}$ [not found]).

Notes. Despite the efforts of the curator at E, the holotype was not found. 
15. Delphinium cruciatum Hossain \& P.H.Davis in Notes Roy. Bot. Gard. Edinburgh 22: 422.1958 [basionym].

$\equiv$ Consolida cruciata (Hossain \& P.H.Davis) P.H.Davis in Notes Roy. Bot. Gard. Edinburgh 26: 174. 1965. Type: Turkey. Adana: "Bozanti", 1896, leg. W. Siehe 362 (holotype: E [E00438700 image!]; isotypes: B [B 100264874 image!], E [E00438699 image!], GH [GH00038199 image!], K [K000692438 image!], P [P00195910!]).

Notes. The specimen E00438700 is explicitly designated as the holotype in the protologue, whereas the indication of collection locality and date is only found on B 10 0264874 and GH00038199.

16. Delphinium deserti-syriaci Zohary in Palestine J. Bot. Jerusalem Ser., 2: 155. 1941 [basionym].

三 Consolida deserti-syriaci (Zohary) Munz in J. Arnold Arbor. 48: 187. 1967a.

三 Aconitella deserti-syriaci (Zohary) Soják in Folia Geobot. Phytotax. Bohem. 4: 448. 1969. Type: Syria. "Azra to Damascus", 16 May 1931, leg. M. Zohary s.n. (holotype: HUJ image!, fragments only).

Notes. The type was partially destroyed during the war (most likely WWII) in Israel (Munz 1967a).

\section{Delphinium flavum DC., Syst. Nat. 1: 346.1817 [basionym].}

E Consolida flava (DC.) Schrödinger in Ann. K. K. Naturhist. Hofmus. 27: 43. 1913. Type: "de Bagdad à Kermancha", s.d., leg. G. A. Olivier \& J. G. Bruguière s.n. (lectotype, designated here: P [P00197330!]; isolectotypes: G-DC [G00200080 image!], P [P00197331!]).

Delphinium flavum DC. var. flavum

= Delphinium flavum DC. var. velutinum DC., Syst. Nat. 1: 346. 1817.

= Delphinium deserti Boiss., Fl. Orient. 1: 83. 1867.

E Consolida deserti (Boiss.) Munz in J. Arnold Arbor. 48: 51. 1967a. Type: «Désert de Suez à Gaza», Jul. 1832, leg. N. Bové 131 (lectotype, designated here: $\mathrm{P}$ [P00197319!] (Fig. 2B); isolectotypes: G [G00440765 image!, G00440766 image!], K [K000076088 image!, K000076089 image!], P [P00197320!]).

Notes. In the protologue of D. flavum, Candolle (1817) described two varieties (var. velutinum and var. glabrum) based on the pubescence and the bracteole position on the pedicel. We synonymize here $D$. flavum var. velutinum with the autonym. Candolle indicates that he saw the specimen in Olivier's herbarium (now at $\mathrm{P}$ ), whereas we found at G-DC a duplicate received in 1822. At P, we found two sheets of the Olivier and 
Bruguière's gathering. It is not sure whether Candolle annotated these sheets. The specimen P00197330 bears the label "dans les lieux incultes steriles de Bagdad a Kermancha" and a mixture of both varieties (the specimen in the bottom right corner corresponds to D. flavum var. glabrum). We designate as lectotype the six other specimens on this sheet.

A single and fragmentary specimen of $D$. deserti, labelled "D. deserti" by Boissier, was found in G-BOIS (G00788308) and probably came from a P duplicate. We designate as lectotype of $D$. deserti the specimen P00197319, the only one bearing a priori an annotation from Boissier.

18. Delphinium glandulosum Boiss. \& Huet in Boiss., Diagn. P1. Orient., Ser. 2, 5: 11.1856 [basionym].

$\equiv$ Consolida glandulosa (Boiss. \& Huet) Bornm. in Repert. Spec. Nov. Regni Veg. Beih. 89: 13. 1936. Type: Turkey. Erzurum: "in cultis Meimansour", Aug. 1853, leg. Huet du Pavillon, A. s.n. (holotype: G-BOIS [G00788286 image!, 3 sheets]; isotypes: BM [BM000553908 image!], G [G00390160 image!, G00390161 image!], GOET [GOET009744 image!], JE [JE00018629 image!, JE00018630 image!, JE00018631 image!, JE00018632 image!], K [K000075573 image!], LE [LE00012145 image!], MO [MO-203061 image!], O [O-V2130694 image!, O-V2130695 image!], P [P00197358!, P00197359! probable], S [S07-14845 image!], UC [UC1055003 image!], WAG [WAG0004719 image!]).

Notes. The description was based on the specimen in G-BOIS, a folder containing three sheets. Only this specimen was annotated by Boissier, which is, therefore, the holotype.

19. Delphinium gombaultii J.Thiébaut in Bull. Soc. Bot. France 81: 114. 1934 [basionym].

E Consolida gombaultii (J.Thiébaut) Munz in J. Arnold Arbor. 48: 175. 1967a. Type: Syria. As-Suwayda: "Djebel Druze”, 21 May 1932, leg. R. Gombault s.n. (holotype: MJSD [MJSD028148 image!]; isotypes: P [P00197360!, P00197361!]).

Notes. Thiébaud (1934) based the species description on the duplicate in his herbarium, which is housed at MJSD. The duplicates at P bear the collection number 1717, which is not indicated on the MJSD specimen.

20. Delphinium halophilum Huth in Bot. Jahrb. Syst. 20: 487. 1895 [basionym].

E Consolida halophila (Huth) Munz in J. Arnold Arbor. 48: 189. 1967a. Type: Iran. "Persia borealis. Gussediche", 1882, leg. T. Pichler s.n. (holotype: G [G00390261 image!]; isotypes: K [K000692367 image!, K000692368 image!]). 
Notes. Huth (1895) based his species description solely on the unicate in the Barbey herbarium (now $\mathrm{G}$ ).

\section{Delphinium hellesponticum Boiss. in Ann. Sci. Nat. Bot. Ser. 2, 16: 366. 1841 [basionym].}

三 Consolida hellespontica (Boiss.) Chater in Feddes Repert. Spec. Nov. Regni Veg. 69: 55. 1964. Type: Turkey. "ad Hellespontum”, Aug. 1836, leg. P. M. R. Aucher-Eloy 67 (holotype: G-BOIS [G00788295 image!, 2 sheets]; isotypes: G [G00440745 image!], K [K000075580 image!], P [P00197463!, P00201125!]).

= Delphinium macedonicum Halácsy \& Charrel in Charrel, Géogr. Bot. Salonique: 8. 1892. 三 Consolida macedonica (Halácsy \& Charrel) Soó in Österr. Bot. Z. 71: 245. 1922.

三 Delphinium hellesponticum subsp. macedonicum (Halácsy \& Charrel) Hossain \& P.H.Davis in Notes Roy. Bot. Gard. Edinb. 22: 419. 1958.

三 Consolida hellespontica subsp. macedonica (Halácsy \& Charrel) Chater in Feddes Repert. Spec. Nov. Regni Veg. 69: 55. 1964. Type: Greece. Thessaloniki: “Kiel tépé [probably Profitis Ilias, SE of Chortiatis fide Strid, 2002]”, s.d., A.-u.-R. Nadji s.n. (holotype: WU (WU033827 image!), isotype: P [P02500001!, P02840902!]) = Delphinium paphlagonicum Huth in Bull. Herb. Boissier 1: 328. 1893.

三 Delphinium olopetalum Boiss. var. paphlagonicum (Huth) Huth, in Engler, Bot. Jahrb. 20: 381. 1895. Type: Turkey. Kastamonu: "Paphlagonia: Wilajet Kastambuli, Tossia", 7 Aug. 1892, leg. P. E. E. Sintenis 4547 (lectotype, designated here: LD [LD1742402 image!], isolectotypes: B [B 100295663 image!, B 100264875 image!], BH image!, GZU [GZU000279189 image!], HAL [HAL0062300 image!], HBG [HBG508807 image!],, P [P00197464!, P00198840!], US [US00103588 image!]).

= Delphinium hellesponticum subsp. aintabense Hossain \& P.H.Davis in Notes Roy. Bot. Gard. Edinburgh 22: 420. 1958. Type: Turkey. "Aintab [Gaziantep]", Jun. 1889, leg. G. E. Post, s.n. (holotype: BM [BM013718242 image!]).

= Delphinium campylopodum Stapf in Denkschr. Acad. Wiss. Wien, Math. Naturw. Kl. 51: 358. 1886.

三Delphinium hellesponticum Boiss. subsp. campylopodon (Stapf) Hossain \& P.H.Davis in Notes Roy. Bot. Gard. Edinburgh 22: 419. 1958. Type: "Owadjik", 1 Aug. 1882, leg. F. Luschan s.n. (lectotype, designated by Chowdhuri et al. 1958, pg. 419): WU [WU0072944 image!]).

Notes. Boissier based the species description of Delphinium hellesponticum on the GBOIS specimens, which is a folder containing two sheets. Only the K duplicate bears a date ("Aug. 1836"). Among the duplicates of Delphinium macedonicum, only P02840902 bears a date (27 avril 1892) and the collection number 37. Huth based his description of Delphinium paphlagonicum on the Sintenis 4547 specimen in his herbarium. The duplicates found in the different herbaria bear different dates, and only LD1742402 (with the date "7 Aug. 1892"), belonging to the Sintenis herbarium, was annotated by Huth, and we treat it as a lectotype. All isotypes indicate herein bear that date. 


\section{Delphinium hispanicum Costa in Anales Soc. Esp. Hist. Nat. 2: 27. 1873 [basionym].}

三 Consolida hispanica (Costa) Greuter \& Burdet in Willdenowia 19: 43. 1989.

$\equiv$ Consolida orientalis (Gay) Schrödinger subsp. hispanica (Willk.) P.W.Ball \& Heywood in Feddes Repert. Spec. Nov. Regni Veg. 66: 151. 1962. Type: Spain. «Linares más arriba de la región de la vid.», 1864, leg. Vivas s.n. (lectotype, designated by Blanché and Simón 2000, pg. 304): BC image!, specimen on the left side).

$=$ Delphinium orientale Gay in Actes Soc. Linn. Bordeaux 11:182. 1840 [nom. illeg.]

三 Consolida orientalis (Gay) Schrödinger in Abh. K. K. Zool.-Bot. Ges. Wien 4(5): 27, 62. 1909. Type: not designated.

= Delphinium bithynicum Griseb. in Spic. Fl. Rumel. 1:320. 1843 [basionym]. Type: Turkey. "Bolu”, s.d., leg. F. Pestalozza s.n. (holotype: GOET [GOET009749 image!]).

Notes. Delphinium orientale Gay was misapplied instead of D. hispanicum in most Floras e.g. "Flora Orientalis" (Boissier 1867), "Flore de l'Afrique du Nord" (Maire 1952), "Flora of Syria, Palestine and Sinaï" (Post 1932), "Flora of Turkey and the East Aegean Islands" (Davis 1965). See Greuter and Raus (1989) for a discussion of the nomenclature.

\section{Delphinium hohenackeri Boiss., Fl. Orient. 1: 85. 1867 [basionym].}

三 Consolida hohenackeri (Boiss.) Grossh., Fl. Kavkaza 2: 101. 1930.

三 Aconitella hohenackeri (Boiss.) Soják in Folia Geobot. Phytotax. Bohem. 4: 448. 1969.

EAconitopsis hohenackeri (Boiss.) Kem.-Nath. in Trudy Tbilissk. Bot. Inst. 7: 127. 1940. Type: Turkey. Bayburt: "Baibout Mt. du Tchorok coteaux arides", 12 Jul. 1862, leg. E. Bourgeau 21 (lectotype (first step designated by Chowdhuri et al. 1958, pg. 415; second-step designated here): G-BOIS [G00788345 image!]; isolectotypes: E [E00438706 image!], JE [JE00018599 image!], LY [LY0042520 image!], P [P04023369!, P00195762!, P00195791!, P00195763!, P00195764!], UC [UC1055009 image!]).

Notes. The designation by Chowdhuri et al. (1958) of Bourgeau 7 at K as the lectotype is corrected herein as a second-step typification from $\mathrm{K}$ (where no Bourgeau's gathering of $D$. hohenackeri was found) to G-BOIS. However, the only Bourgeau's gathering of D. hohenackeri at G-BOIS bears the collection number 21. In contrast, Bourgeau 7 is found at E, JE, LY, P, and UC (sub D. anthoroideum), usually on printed Bourgeau's collection labels. 


\section{Delphinium incanum E.D.Clarke, Travel 2(1): 451.1812 [basionym].}

$\equiv$ Consolida incana (E.D.Clarke) Munz in J. Arnold Arbor. 48: 181. 1967a. Type: Israel: "Migdal", 13 Jun. 1942, leg. P. H. Davis 4819 (neotype, designated by Munz 1967a, pg. 181: BM [BM013718647 image!]; isoneotype: E [E00438698 image!]).

= Delphinium exsertum DC., Syst. Nat. 1: 345.1817 [basionym]. Type: sine loco, Labillardière, J. J. (holotype: FI [FI058566 image!; isotype: FI [FI058565 image!]).

= Delphinium rigidum DC., Syst. Nat. 1: 344. 1817.

三 Consolida rigida (DC.) Bornm. in Beih. Bot. Bot. Centralbl., Abt. 2. 31: 181. 1914. Type: "Syria”, s.d., leg. J. J. Labillardière s.n. (holotype: G [G00390153 image!]).

Notes. Munz (1967a) designated an isoneotype for D. incanum at K, which was not found. At FI, the specimen FI058564 could correspond to a duplicate of the type material of $D$. rigidum.

25. Delphinium intrincatum Pau in Trab. Mus. Cienc. Nat. Ser. Bot. 14: 12.1918 [basionym].

$\equiv$ Consolida teheranica (Boiss.) Rech. f. var. intrincata (Pau) Parsa, Fl. Iran 2: 326. 1986.

三 Aconitella intrincata (Pau) C.Blanché \& J.Molero in Bot. J. Linn. Soc. 113: 127. 1993. Type: Iran. «Kouh-Cherri (Alto Karum)», 23 Jul. 1899, leg. M. de la Escalera s.n. (lectotype, designated by Blanché and Molero 1993, pg. 127: MA [MA39257 image!]).

Notes. No duplicate of the type collection was found in the different herbaria consulted.

26. Delphinium kabulianum Akhtar in Bull. Misc. Inform. Kew 1938: 86. 1938 [basionym].

EConsolida kabuliana (Akhtar) Iranshahr in Fl. Iranica 171: 102. 1992.

三 Consolida stocksiana (Boiss.) Nevski var. kabuliana (Akhtar) Tamura in Kitamura, Fl. Afghan. 124. 1960. Type: Afghanistan. "near Kabul", 23 Aug. 1937, leg. S. A. Akthar (holotype: K [K000692442 image!]).

Notes. No duplicate of the type collection was found in the different herbaria consulted. 
27. Delphinium kandaharicum (Iranshahr) Jabbour in Global Fl. 4(1): 73. 2018.

E Consolida kandaharica Iranshahr in Pl. Syst. Evol. 155: 56.1987 [basionym]. Type: Afghanistan. Kandahar: "versus lacum artificiale / Arghandab Reservoir”, 22-23 May 1967, leg. K. H. Rechinger 34869 (holotype: W [W19840011834 image!]).

Notes. No duplicate of the type collection was found in the different herbaria consulted.

28. Delphinium leptocarpum (Nevski) Nevski in Fl. URSS 7: 110.1937

E Consolida leptocarpa Nevski in Acta Inst. Bot. Acad. Sci. URSS 4: 296.1937 [basionym]. Type: «Ak-Davan», 21 Jun. 1931, S. A. Nevski 364 (holotype: LE [LE00050815 image!]; isotype: K [K000692381 image!]).

Notes. Although Nevski annotated both duplicates at LE and K, the latter is clearly labelled "Dupla", and we considered LE00050815 as the holotype.

29. Delphinium linarioides Boiss. in Ann. Sci. Nat. Bot. ser. 2, 16: 368.1841 [basionym].

三 Consolida linarioides (Boiss.) Munz in J. Arnold Arbor. 48: 191. 1967a. Type: Iran. "Ispahan", s.d., leg. P. M. R. Aucher-Eloy 4029 (lectotype, designated here: G-BOIS [G00788305 image!]; isolectotypes: G [G00440762 image!], K [K000692379 image!], P [P00198677!, P00198678!]).

Notes. Boissier's annotation is found on P00198677 and G00788305, indicating Boissier based the species description on these duplicates. Therefore, the lectotypification is justified.

30. Delphinium lineolatum (Huber-Morath \& C.Simon) Jabbour in Global Fl. 4(1): 73. 2018.

三 Consolida lineolata Huber-Morath \& C.Simon in Bauhinia 6: 285. 1978 [basionym]. Type: Turkey. Ermenek: "41 km sw Mut", 13 Jul. 1976, leg. M. Nydegger 11138 (holotype: BASBG [BASBG-00000081 image!]; isotype: G [G00440764 image!, 3 sheets], GOET [GOET009747 image!]).

Notes. The protologue and G00440764 indicate erroneously that the collection number is 1138 when it is 11138 . 
31. Delphinium lorestanicum (Iranshahr) Jabbour in Global Fl. 4(1): 73. 2018.

$\equiv$ Consolida lorestanica Iranshahr in Pl. Syst. Evol. 155: 55.1987 [basionym]. Type: Iran. Lorestan: "10-20 km on road from Aligodarz to Shoulabad", 2 July 1977, leg. Runemark \& Lazari 26530 (holotype: TARI image!).

Notes. No duplicate of the type collection was found in the different herbaria consulted.

32. Delphinium mauritanicum Cosson in Bull. Soc. Bot. France 27: 68. 1880 [basionym].

E Consolida mauritanica (Cosson) Munz in J. Arnold Arbor. 48: 48. 1967b. Type: Algeria. Oran: "Champs incultes à Lalla-Maghrnia", 24 May 1856, leg. E. Bourgeau s.n. (lectotype, designated here: P [P02336111!]; isolectotypes: K [K001394825 image!], P [P02379147!]).

Notes. In his protologue, Cosson quotes several syntypes. Munz (1967b) designated the gathering Bourgeau at $\mathrm{P}$ as type. We found two duplicates at $\mathrm{P}$, of which only P02336111 bears an annotation from Cosson.

\section{Delphinium oliverianum DC., Syst. Nat. 1: 341.1817 [basionym].}

三 Consolida oliveriana (DC.) Schrödinger in Abh. K. K. Zool.-Bot. Ges. Wien 4(5): 62. 1909. Type: Irak. «de Bagdad à Kermachan», s.d., leg. G. A. Olivier \& J. G. Bruguière s.n. (holotype: P [P00198747!]).

Notes. No specimen was found at G. Candolle (1817) based on the species description on the unicate in Olivier's herbarium, which is housed at $\mathrm{P}$.

34. Delphinium olopetalum Boiss. in Ann. Sci. Nat. Bot. Ser. 2, 16: 364.1841 [basionym], non sensu Hayek in Repert. Spec. Nov. Regni Veg. Beih. 30(1): 313. 1924.

E Consolida armeniaca (Huth) Schrödinger var. olopetala (Boiss.) Parsa, Fl. Iran. 2: 316. 1986. Type: "Perse ?", 1837, leg. P. M. R. Aucher-Eloy, s.n. (holotype: P [P00198568!]).

Notes. No specimen was found in Boissier's herbarium. Boissier's annotation on P00198568 indicates that the species description is based on this unicate ("exemplar unicum"), which is the holotype. Boissier (1841) indicated that the collection was mixed with $D$. tomentosum, which is no longer the case. 


\section{Delphinium paradoxum Bunge in Arbeiten Naturf. Vereins Riga 1: 124. 1847 [basionym].}

三 Consolida paradoxa (Bunge) Nevski in Komarov, V. L., Fl. URSS 7: 113. 1937.

$\equiv$ Consolida rugulosa (Boiss.) Schrödinger f. paradoxa (Bunge) Iranshahr in Fl. Iranica 171: 105. 1992. Type: Iran. "Djan-Darja”, 3 May 1842, leg. A. Lehman 36 (lectotype, designated here: P00198841, isolectotypes: BM [BM000946072 image! =photo of LE], GH [GH00038197 image!], H [H1506244 image!], K [K000692370 image!], LE).

Notes. When describing new species, Bunge usually annotated the specimens cited with "mihi" or "m." behind the species name. Unfortunately, we did not find any annotation from Bunge on the different duplicates. P00198841 bears ten individuals and three different preprinted Lehmann's collection labels, all corresponding to collection number 36. One of them is from Lehmann's hand with the locality (in Latin) and the date indicated in the protologue. No date is indicated on the other duplicates. LE (photo seen at BM) bears a label with the locality translation in German. After an investigation by the curator, the LE specimen was not found.

36. Delphinium persicum Boiss. in Ann. Sci. Nat. Bot. Ser. 2, 16:362. 1841 [basionym].

三 Consolida persica (Boiss.) Schrödinger in Abh. K. K. Zool.-Bot. Ges. Wien 4(5): 17. 1909. Type: Iran. "Persia Circa Amadan", 1837, leg. P. M. R. Aucher-Eloy 78 (holotype: G-BOIS [G00150139 image!]; isotypes: G [G00192123 image!, G00192122 image!]; K [K000692364 image!]; P [P00198487!, P00198912!]).

Notes. Boissier based the species description on the duplicate in G-BOIS. The date "1837" is only indicated on the isotypes housed at G and P.

37. Delphinium phrygium Boiss. in Ann. Sci. Nat. Bot. Ser. 2, 16: 363.1841 [basionym].

$\equiv$ Delphinium ajacis L. var. phrygium Fin. \& Gagnep. in Bull. Soc. Bot. France 51: 467. 1904.

三 Consolida phrygia (Boiss.) Soó in Österr. Bot. Z. 71: 245. 1922.

三 Consolida orientalis (Gay) Schrödinger subsp. phrygia (Boiss.) Chater in Feddes Repert. Spec. Nov. Regni Veg. 68: 193. 1963. Type: Turkey. “in Phrygia”, 1831, leg. P. M. R. Aucher-Eloy 71 (holotype: P [P00198754!]; isotype: G-BOIS [G00789467 image! fragments only]).

Notes. Duplicate found in G-BOIS correspond to fragments taken from P00198754, which bears an original collection label, and was examined and annotated by Boissier for the species description. 


\subsection{Delphinium phrygium Boiss. subsp. phrygium}

\subsection{Delphinium phrygium Boiss. subsp. thessalonicum (Soó) Jabbour \& Du Pas- quier, comb. nov.}

urn:Isid:ipni.org:names:77218868-1

三 Consolida orientalis (Gay) Schrödinger var. thessalonica Soó in Österr. Bot. Z. 71: 239. 1922 [basionym].

三 Consolida phrygia (Boiss.) Soó subsp. thessalonica (Soó) P.H.Davis in Notes Roy. Bot. Gard. Edinburgh 26: 174. 1965. Type: Greece. Thessalia: "Kalampaka", 4 Jun. 1896, leg. P. E. E. Sintenis 579 (holotype: not found; isotypes: E [E00346595 image!], LD [LD1742978 image!], P [P02500761!, P02574100!, P02819490!, P02819491!]).

Notes. Describing the subspecies, Soó indicated two herbaria (the herbarium of the National Museum of Hungary and Borbás' herbarium), which are at BP now. However, after an investigation by the curators, no type specimen was found. None of the isotypes cited herein are annotated by Soó. More investigation is needed to argue that the $\mathrm{BP}$ specimens are lost before designating any lectotype.

\section{Delphinium pubescens DC. in Lam. \& DC., Fl. Franç., Ed. 3 5: 641. 1815 [basionym].}

三Consolida pubescens (DC.) Soó in Österr. Bot. Z. 71: 241.1922.

$\equiv$ Delphinium consolida L. subsp. pubescens (DC.) Nyman Consp. Fl. Eur. 21. 1878.

Type: France. Occitanie: «lieux cultivés près Fontfroide», 12 Jun. 1807, A. P. Can-

dolle s.n. (lectotype, designated here: G00131934 image!).

= Delphinium loscosii Costa in Anales Soc. Esp. Hist. Nat. 2: 26. 1873.

$\equiv$ Delphinium pubescens DC. subsp. loscosii (Costa) Graeber \& Graeber fil., in Asch. \& Graebn., Syn. Mitteleur. Fl., 5(2): 676. 1929.

$\equiv$ Delphinium consolida L. var. loscosii (Costa) Pau, in Not. Bot. Fl. Espań. 4: 12. 1891. 三 Consolida loscosii (Costa) Holub., in Novit. Bot. Delect. Seminum Horti Bot. Univ. Carol. Prag. 1960: 4. 1960.

三 Consolida pubescens (DC.) Soó subsp. loscosii (Costa) Soó, in Österr. Bot. Z. 71: 241. 1922.

三 Consolida pubescens (DC.) Soó var. loscosii (Costa) P.W.Ball \& Heywood, in Feddes Repert. Spec. Nov. Regni Veg. 66: 151. 1962. Type: Spain. "in Aragonia australis pratis arvisque quoque in Catalaunia”, s.d., leg. A. C. Costa s.n. (lectotype, designated by Blanché and Simon 2000, pg. 307: BC [BC-975765 image!]).

Notes. Candolle did not mention any specimen in his protologue when he described D. pubescens. Although some original material of the "Flore Française" can be at MPU or P (Stafleu 1967), where Candolle worked before moving to Geneva, we found a 
Candolle's gathering dated 1807 at $\mathrm{G}$ in the prodromus herbarium, that we designate as the lectotype.

\section{Delphinium pusillum Labill., Icon. Pl. Syr. 4: 5. 1812 [basionym].}

三 Consolida pusilla (Labill.) Schrödinger in Abh. K. K. Zool.-Bot. Ges. Wien 4(5): 62. 1909. Type: Syria. "Djebel Cher", s.d., leg. J. J. Labillardière s.n. (holotype: FI [FI005591 image!).

= Delphinium pygmaeum Poiret in Lam., Encycl. Suppl. 2: 458. 1812.

三 Consolida pygmaea (Poiret) Schrödinger in Ann. K. K. Naturhist. Hofmus. 27: 43.

1913. Type: "Syrie", s.d., leg. J. J. H. Labillardière s.n. (holotype: FI [FI005590 image!]; isotype: P [P04023292!]).

= Delphinium oliganthum Boiss. Fl. Orient. 1: 80. 1867.

三 Consolida oligantha (Boiss.) Schrödinger in Ann. K. K. Naturhist. Hofmus. 27: 43.1913.

$\equiv$ Consolida tomentosa (Boiss.) Schröd. subsp. oligantha (Boiss.) P.H.Davis in Notes

Roy. Bot. Gard. Edinburgh 26: 175. 1965. Type: Syria. "In agris apris: p. Assy. p Aintab”, 27 Jun. 1865, leg. H. C. Haussknecht s.n. (lectotype (first step designated by Chowdhuri et al. 1958, pg. 417, second-step designated here): G [G00788351a image!, not G00788351]; isotypes: G [G00390259 image!, specimen in the middle only], K [K000075574 image!, two specimens annotated as “3”], P [P00198731!, P00550831!, P00198733!, P00198737!]).

Notes. The holotype of $D$. pusillum bears a handwritten protologue by Labillardière. Munz (1967a) indicated that he saw an isotype of D. pusillum at K (obviously K000692380), but it is not clear whether this specimen belongs to the type collection or not.

As explained by Chowdhuri et al. (1958), when dealing with D. oliganthum, the Haussknecht's gathering housed at $\mathrm{G}$ and $\mathrm{K}$ is a mixed collection of $D$. hellesponticum and D. oliganthum. In the Boissier herbarium, the folder of D. oliganthum contains two sheets, one with $D$. hellesponticum (G00788351), which bears the original label, and the other one with D. oliganthum (G00788351a), both annotated in 1956 by M. Hossain, one of the co-authors with P. K. Chowdhuri and P. H. Davis. At G, K and P duplicates also contain both species. We complete the first step of lectotypification by Chowdhuri et al. (1958), who indicated G and K simultaneously in designating the specimen on the sheet G00788351a at G-BOIS as the second-step lectotype.

\section{Delphinium raveyi Boiss., Diagn. Pl. Orient. 1: 66. 1843 [basionym].}

三 Consolida raveyi (Boiss.) Schrödinger in Abh. K. K. Zool.-Bot. Ges. Wien 4(5): 62. 1909. Type: Turkey. Aydin: "in arvis Cariae ad Geyra", Jun. 1842, leg. P. E. Boissier s.n. (lectotype, designated here: G-BOIS [G00330114 image!, 5 sheets]; isolecto- 
types: BM [BM000553909 image!], G [G00390157 image!, 2 sheets, G00390156 image!], GOET [GOET009748 image!], JE [JE00018604 image!, JE00018605 image!, JE00018606 image!], K [K000692363 image!, K000692382 image!], MEL [MEL2409727 image!], NY [NY00353414 image!, NY00353415 image!], P [P00344101!, P00198977!, P00198978!, P00198979!], S [S07-15317 image!], US [US00409759 image!]).

Notes. Boissier annotated P00198978 and, therefore, we designate as lectotype the duplicate, including five sheets, in his herbarium.

41. Delphinium rugulosum Boiss. in Ann. Sci. Nat. Bot. Ser. 2, 16: 361.1841 [basionym].

$\equiv$ Delphinium camptocarpum Fisch. \& C.A.Meyer var. rugulosum (Boiss.) Bunge in Arb. Naturf. Ver. Riga 1: 126. 1848.

$\equiv$ Consolida rugulosa (Boiss.) Schrödinger in Ann. K. K. Naturhist. Hofmus. 27: 43. 1913. Type: Iran." ad lacum Ourmiah", s.d., leg. P. M. R. Aucher-Eloy 4028 (holotype: G-BOIS [G00150138 image!]; isotypes: BM [BM000570952 image!], G [G00192124 image!], K [K000692365 image!, K000692366 image!], P [P00198502!, P00198503!, P00198504!, P00198505!]).

Notes. Boissier based the species description on the unicate at G-BOIS.

42. Delphinium saccatum Huth in Bull. Herb. Boissier 1: 328.1893 [basionym].

$\equiv$ Consolida saccata (Huth) P.H.Davis in Notes Roy. Bot. Gard. Edinburgh 26: 173. 1965.

三Aconitella saccata (Huth) Soják in Folia Geobot. Phytotax. Bohem. 4: 448. 1969.

三 Aconitopsis saccata (Huth) Kem.-Nath. in Trudy Tbilissk. Bot. Inst. 7: 127. 1939.

Type: Turkey. "Mardin: Rischemil, in lapidosis", 28 Jun. 1888, leg. P. E. E. Sintenis 1186 (lectotype, designated here: LD [LD1016965 image!]; isolectotypes: BR [BR0000005295852 image!], E [E00438701 image!], G [G00440763 image!], JE [JE00018615 image!, JE00018616 image!, JE00018617 image!, JE00018618 image!], K [K000692359 image!, K000692360 image!], LD [LD1017157 image!], MO [MO-2196034], P [P00198522!, P00198523!, P00198524!], PH [PH00010734 image!], S [S07-15323 image!]).

Notes. Huth (1893) saw the Sintenis 1186 specimen at B (but destroyed during WWII) and in his personal herbarium. Among the duplicates, we found specimens annotated by Huth at K (K000692359) and LD (LD1016965). Therefore, their lectotypification was needed. 
43. Delphinium samium (P.H.Davis) Jabbour in Global Fl. 4(1): 73. 2018.

E Consolida samia P.H.Davis in Notes Roy. Bot. Gard. Edinburgh 26: 172.1965 [basionym]. Type: Greece, North Aegean. "Samos. SW-slope of Mt. Kerki", 26 May 1963, leg. H. Runemark \& S. E. Snogerup 19592 (holotype: LD [LD1023318 image!]; isotype: E [E00202626 image!]). Davis (1965) indicated that the holotype was kept at LD.

44. Delphinium schlagintweitii Huth in Bull. Herb. Boiss. 1: 329.1893 [basionym].

E Consolida schlagintweitii (Huth) Munz in J. Arnold Arbor. 48: 191. 1967a. Type: Pakistan. Gilgit-Baltistan: "Bálti. Environs of Skárdo", 6 Aug.-4 Sep. 1856, leg. A. Schlagintweit 821 (holotype: G [G00390260 image!]; isotypes: B [destroyed], BM [BM000553907 image!], MEL [MEL2407606 image!], US [US00409758 image!]).

Notes. Huth based his description solely on the duplicate in the Barbey herbarium (now $\mathrm{G}$ ).

\section{Delphinium sclerocladum Boiss., Diagn. Pl. Orient. 8: 8. 1849 [basionym].}

Delphinium anthoroideum Boiss. var. sclerocladum (Boiss.) Boiss. Fl. Orient. 1: 85. 1867. $\equiv$ Consolida scleroclada (Boiss.) Schrödinger in Ann. K. K. Naturhist. Hofmus. 27: 44. 1913.

EAconitella scleroclada (Boiss.) Soják in Folia Geobot. Phytotax. Bohem. 4: 448. 1969. 三 Aconitopsis scleroclada (Boiss.) Kem.-Nath. in Trudy Tbilissk. Bot. Inst. 7: 127. 1940.

Type: Syria. Latakia: “montagnes de Latakieh”, May-Jul. 1846, leg. P. E. Boissier s.n. (lectotype, designated here: G-BOIS [G00788332 image!, 3 sheets]; isolectotypes: E [E00438707 image! =photo of G-DC], G-DC, P [P00195757!, P00195758!]).

Notes. Boissier annotated P00195758. Therefore the lectotypification is justified. The G-DC specimen (observed only on the photo at E) bears the date "Jun 1846". A specimen at JE (JE00018613) could probably be part of the type material.

\subsection{Delphinium sclerocladum Boiss. var. sclerocladum}

45.2. Delphinium sclerocladum Boiss. var. rigidum (Freyn \& Sint.) Hossain \& P.H.Davis in Notes Roy. Bot. Gard. Edinburgh 22: 414.1958.

三Delphinium anthoroideum Boiss. var. rigidum Freyn \& Sint. in Österr. Bot. Z. 41: 363. 1891 [basionym]. 
$\equiv$ Consolida scleroclada (Boiss.) Schrödinger var. rigida (Freyn \& Sint.) P.H.Davis, Fl. Turkey 1: 123. 1965.

三 Consolida euphratica Schrödinger in Ann. K. K. Naturhist. Hofmus. 27: 43. 1913. Type: Turkey. "Chama ad Euphratem. Ichtik prope Tuzla", 15 Jul. 1890, leg. P. E. E. Sintenis 2969 (lectotype, designated here: P [P00195794!] (Fig. 2C); isolectotype: LD [LD1011461 image!]).

Notes. Contrary to the quotation of Hossain and Davis in their protologue, the type specimen was found neither at W nor at WU (probably destroyed during WWII). At JE, the specimen Sintenis 2969 (JE00018614) does not correspond to type material since it bears the mention "Erzinghan: in declivibus ad Euphratem prop. Sürek" with the date 17 Jul. 1890. In 1913, Schrödinger recombined the varietal rank "rigidum" by renaming it as Consolida euphratica. He quoted as synonym $D$. anthoroideum var. rigidum Freyn \& Sint. In order to resolve both names simultaneously, we designate the specimen "Sintenis 2969 " at $\mathrm{P}$ as lectotype of D. anthoroideum var. rigidum Freyn \& Sint. and C. euphratica Schrödinger.

\section{Delphinium songoricum (Kar. \& Kir.) Nevski, in Komarov, V. L., Fl. URSS 7: 109.1937.}

三 Delphinium camptocarpum Fisch. \& C.A.Mey. var. songoricum Kar. \& Kir. in Bull. Soc. Nat. Mosc. 15:136. 1842 [basionym].

E Consolida songorica (Kar. \& Kir.) Nevski in Komarov, V. L., Fl. URSS 7: 109. 1937. Type: Russia. "In arenosis Songoriae ad fl. Lepsa", 1841, leg. G. S. Karelin \& I. P. Kirilow 1165 (holotype: LE, not found; isotypes: BM [BM000946032 image!], H [H1252673 image!], K [K001394824 image!], NY [NY00353417 image!], P [P00197046!, P00197047!]).

Notes. The holotype should be at LE (indicated by Nevski 1937), although we did not find it.

47. Delphinium staminosum (P.H.Davis \& Sorger) Jabbour in Global Fl. 4(1): 73. 2018.

三 Consolida staminosa P.H.Davis \& Sorger in Notes Roy. Bot. Gard. Edinburgh 40: 89. 1982 [basionym]. Type: Turkey. Niğde: "Çaykavak pass”, 19 Jul. 1979, leg. Hübl, Meusel \& Valant 7-19-13 (holotype: E [not found]; isotype: LI [LI02796901 image!]).

Notes. Despite investigations by the curators, the specimen at $\mathrm{E}$ was not found, and contrary to what Davis and Sorger indicated in their protologue, duplicates were found neither at WU nor at W. 
48. Delphinium stapfianum (P.H.Davis \& Sorger) Jabbour in Global Fl. 4(1): 73. 2018.

三 Consolida stapfiana P.H.Davis \& Sorger in Notes Roy. Bot. Gard. Edinburgh 40: 89. 1982 [basionym]. Type: Turkey. Antalya: "20 km SW of Korkuteli, 1200 m, field margins”, 12 Jul. 1968, leg. F. Sorger 68-27-11 (holotype: E, not found; isotype: LI [LI02796918 image!]).

Notes. Despite investigations by the curators, the specimen at E was not found.

49. Delphinium stenocarpum Hossain \& P.H.Davis in Notes Roy. Bot. Gard. Edinburgh 22: 413.1958 [basionym].

三 Consolida stenocarpa (Hossain \& P.H.Davis) P. H. Davis in Notes Roy. Bot. Gard. Edinburgh 26: 173. 1965.

三 Aconitella stenocarpa (Hossain \& P.H.Davis) Soják in Folia Geobot. Phytotax. Bohem. 4: 448. 1969. Type: Turkey. Konya: "between Ağabeyli and Körkuyu", 8 Sep. 1949, leg. P. H. Davis 16638 (holotype: E [E00438702 image!]; isotypes: K [K000692450 image!, K000692449 image!]).

Notes. Hossain and Davis formally designated the holotype of Delphinium stenocarpum at E, where we found E00438702 annotated by themselves.

50. Delphinium stocksianum Boiss., Diagn. Pl. Orient., Ser. 2, 1: 12.1853 [basionym].

E Consolida stocksiana Nevski in Komarov, V. L., Fl. URSS 7: 111. 1937. Type: Pakistan. "Baluchistan", 1851, leg. J. E. Stocks 979 (holotype: G-BOIS [G00789496 image!, 3 sheets]; isotypes: K [K000075584 image!, K000075586 image!, K000075587 image!]).

Notes. The holotype is a folder of three sheets.

51. Delphinium sulphureum Boiss. \& Hausskn. in Boiss., Fl. Orient. 1: 81. 1867 [basionym].

E Consolida sulphurea (Boiss. \& Hausskn.) P.H.Davis in Notes Roy. Bot. Gard. Edinburgh 26: 175. 1965. Type: Turkey. Maraş: "Montes azia/ Marasch”, 1865, leg. H. C. Haussknecht s.n. (holotype: G-BOIS [G00788353 image!, 2 sheets]; isotype:

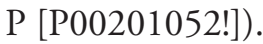

Notes. In the protologue, Boissier quoted an unnumbered Haussknecht's collection with the following indication "in graminosis montium Syriae borealis prope Marasch alt. 4000"”. 
Davis (1965) indicated as "types" a specimen housed at K. However, Boissier did not examine this specimen and based his description solely on specimens in his herbarium, where we found a collection folder containing two sheets. One bears a printed label of Haussknecht's collection with his handwritten additions of locality "In apris v. Karabigukle et pr. Marasch", and the date "Aug. 65". The other one bears three of Boissier's handwritten labels, one of which bears the mention of the locality "Montes azia/ Marasch" and the date "1865".

At JE, K, and P, we found Haussknecht's duplicates (JE00018589, K000692378, and P00201052) with a label handwritten by himself bearing the locality "Uffoschikle" (or "Uffoschakli") with the date 11 July 1865. A duplicate at JE bears, in addition, the number 970. All these specimens correspond to syntypes.

\section{Delphinium teheranicum Boiss., Fl. Orient. 1: 85.1867 [basionym].}

三 Consolida teheranica (Boiss.) Rech. f. in Ann. Nat. Mus. Wien 51: 376. 1940.

三Aconitella teheranica (Boiss.) Soják in Folia Geobot. Phytotax. Bohem. 4: 448. 1969. 三Aconitopsis teheranica (Boiss.) Kem.-Nath. in Trudy Tbilissk. Bot. Inst. 7: 1271940.

Type: Iran. "Teheran”, leg. C. G. T. Kotschy, s.n. (lectotype, designated here: GBOIS [G00788331 image!]).

Notes. In the protologue, Boissier (1867) based the species description on the specimen Kotschy 884 housed at W ("in herb. Mus. Vindob!"). Iranshahr (1992) indicated to have seen this specimen at G. However, after investigation, the specimen Kotschy 884 was found neither at W, nor at WU, nor G. In G-BOIS, we found a Kotschy's gathering of $D$. teheranicum with a fragmentary specimen (probably a part of the specimen cited in the protologue) and a label written by Boissier. We designate this specimen as the lectotype.

\section{Delphinium tenuissimum Sm., Fl. Graec. Prodr. 1: 370.1809 [basionym].}

E Consolida tenuissima (Sm.) Soó in Österr. Bot. Z. 71: 241. 1922. Type: Greece. Sterea Ellas: "Mt Hymethus", s.d., leg. J. Sibthorp s.n. (holotype: OXF [Sib-1234 image!], isotype: BM [BM000613696 image!]).

Notes. Sibthorp's herbarium is housed at OXF, where we found a duplicate bearing the locality annotation "Mt Hymethus".

\section{Delphinium thirkeanum Boiss., Fl. Orient. 1: 84.1867 [basionym].}

三 Consolida thirkeana (Boiss.) Schrödinger in Abh. K. K. Zool.-Bot. Ges. Wien 4(5): 62. 1909.

EAconitella thirkeana (Boiss.) Soják in Folia Geobot. Phytotax. Bohem. 4: 448. 1969. 
EAconitopsis thirkeana (Boiss.) Kem.-Nath. in Trudy Tbilissk. Bot. Inst. 7: 125. 1940. Type: Turkey. "Amasia et Tokat", s.d., F. Wiedemann s.n. (lectotype, designated here: G-BOIS [G00788335 image!], isolectotype: E [E00438704 image! =photo of $\mathrm{G}-\mathrm{BOIS}])$.

Notes. In his protologue, Boissier (1867) cited two gatherings: "in Bithynia, Thirke" and "circa Amasia et Tokat Anatoliae, Wiedem.". Wiedemann's gathering at G-BOIS is here chosen as lectotype. Munz (1967a) indicated that he saw a duplicate of this gathering at $\mathrm{GH}$ and $\mathrm{K}$. However, the duplicate at GH could not be found by the curator. It is unclear whether the Wiedemann's gathering at K of D. thirkeanum (K000075588), which is apparently a duplicate from a specimen at LE, belongs to the type material. Moreover, Huth (1895) quotes a specimen at LE, which was not observed.

55. Delphinium tomentosum Boiss. in Ann. Sci. Nat. Bot. Ser. 2, 16: 365.1841 [basionym].

三 Consolida tomentosa (Boiss.) Schrödinger in Abh. K. K. Zool.-Bot. Ges. Wien 4(5): 62. 1909. Type: Syria. "Persia", 1836, P. M. R. Aucher-Eloy 77 (lectotype, designated here: P [P00201127!] (Fig. 2D)).

Notes. In his protologue, Boissier cited two gatherings of Aucher-Eloy: "N.76. Alep" and "77. Persia". Chowdhuri et al. (1958. 22: 418) erred in designating as lectotype the gathering Aucher 75 "Syria!" that Boissier (1841) indicated under Delphinium virgatum Poir. (in fact, Aucher 75 corresponds to D. peregrinum L.). No sheet of Aucher 76 bears any annotation from Boissier, whereas P00201127 (Aucher 77) is annotated. We designate this latter specimen as the lectotype. No duplicate was found.

56. Delphinium trigonelloides Boiss. in Ann. Sci. Nat. Bot. Ser. 2, 16: 366.1841 [basionym].

三 Consolida trigonelloides (Boiss.) Munz in J. Arnold Arbor. 48: 190. 1967a. Type: Iran. "Pers. australi", s.d., leg. P. M. R. Aucher-Eloy 4033 (holotype: G-BOIS [G00788304 image!]; isotypes: BM [BM000570953 image!], G [G00440760 image!, G00440761 image!], K [K000692375 image!], P[P00201193!, P00201194!]).

Notes. Boissier based his species description on the duplicate of his herbarium.

\section{Delphinium tuntasianum Halácsy in Magyar Bot. Lapok 11: 117. 1912 [basionym].}

三 Consolida tuntasiana (Halácsy) Soó in Österr. Bot. Z. 71: 239. 1922. Type: Greece. Sterea Ellas: "in regione abietina m. Gerania Megarae", 23-28 Jun. 1910, B. Tun- 
tas 1245 (lectotype, designated here: WU [WU 01067863 image!, specimen on the bottom left corner]).

Notes. Halácsy based his description of D. tuntasianum on the specimen Tuntas 1245 from the "Plantae exsiccatae Florae Hellenicae" collection. Three Tuntas specimens of D. tuntasianum, each one including several plant individuals, were found at WU: Tuntas 1245, Tuntas 800, and Tuntas s.n. Examination of Tuntas 1245 shows two different dates: "23-28 Jun. 1910" (printed) and "10/23 Mai 1911" (handwritten), this later date being the same as the gathering "s.n.". Therefore, the gathering "1245" is probably a combination of two different collections. We designate it as a lectotype despite the uncertainty regarding its collection date.

58. Delphinium uechtritzianum Huth in Bot. Jahrb. Syst. 20: 378.1895 [basionym].

E Consolida uechtritziana (Huth) Soó in Österr. Bot. Z. 71: 236. 1922. Type: Albania. "In arvis ad Zojz", 1889, leg. A. Baldacci s.n. (lectotype, designated here: G [G00414314 image!, 2 sheets]).

Notes. In his protologue, Huth quotes two syntypes (Pančic 1881 seen in three different herbaria, and Baldacci 1889 seen in the Barbey herbarium, now G). At G, there is a folder with two sheets of the second gathering that we designate here as lectotype.

\section{Discussion and conclusions}

According to the nomenclatural revision presented here, Delphinium subg. Consolida consists of 58 species. This work will facilitate a taxonomic study aimed at revising the circumscription of sections within $D$. subg. Consolida. Infrasubgeneric relationships were tackled and discussed in Jabbour and Renner (2011). Moreover, a thorough taxonomic study of the species-rich subgenera Delphinastrum (DC.) Peterm. and Oligophyllon Dimitrova is now timely, as they are the last subgenera in Delphinium that still require revision.

\section{Acknowledgements}

We would like to warmly thank Gabrielle Barriera (Conservatoire et Jardin Botaniques de la Ville de Genève, Switzerland) for her invaluable help in disentangling many conflicting nomenclatural points. We also thank the curators of ATHU, B, BASBG, BC, BEI, BH, BM, BP, BR, C, E, FI, FR, G, GB, GH, GOET, GZU, H, HAL, HBG, HUJ, ISL, JE, K, L, LD, LE, LI, LY, MJSD, MA, MEL, MO, NY, O, OXF, PAD, PH, S, TARI, UC, UPS, US, W, WAG, WRSL, and WU for their kind assistance, and Dieter Reich and Christian Braüchler for their valuable suggestions. 
We thank three reviewers (Andrey Erst, Andriy Novikov, Martyn Rix) and the Editor (Marco Pellegrini) for their helpful comments on the manuscript. The MNHN gives access to the collections in the framework of the RECOLNAT national research infrastructure.

\section{References}

Al-Shehbaz IA, Barriera G (2019) Typification of Edmond Boissier's Cruciferae (Brassicaceae) names enumerated in Flora Orientalis. Boissiera 72: 5-192.

BlanchéC, Molero J (1993) Taxonomicand nomenclatural notes on Delphinium L. Botanical Journal of the Linnean Society 113(2): 125-133. https://doi.org/10.1111/j.1095-8339.1993. tb00334.x

Blanché C, Simon J (2000) Sobre Algunos Delphinium L. de Loscos. In: Instituto de Estudios Turolenses (Eds) Congreso de Botánica en homenaje a Francisco Loscos (1823-1886). Instituto de Estudios Turolenses, Turin, 303-312.

Boissier PE (1841) Plantae Aucherianae orientales enumeratae cum novarum specierum descriptione. Annales des Sciences Naturelles. Botanique 16(2): 347-377.

Boissier PE (1867) Flora orientalis sive enumeration plantarum in Oriente a Graecia et Aegypto ad Indiae fines hucusque observatarum. Vol. 1. Georg H, Genève, Bâle \& Lyon, 1017 pp. https://doi.org/10.5962/bhl.title.20323

Candolle AP de (1817) Regni vegetabilis systema naturale, sive ordines, genera et species plantarum secundum methodi naturalis normas digestarum et descriptarum. Vol. 1. Treuttel \& Würtz, Paris, 564 pp. https://doi.org/10.5962/bhl.title.59874

Candolle AP de (1824) Prodromus systematis naturalis regni vegetabilis, sive enumeratio contracta ordinum, generum, specierumque plantarum hucusque cognitarum, juxta methodi naturalis normas digesta. Vol. 1. Treuttel et Würtz, Paris, 748 pp. https://doi.org/10.5962/ bhl.title.286

Chater AO (1993) Consolida (DC.) S.F. Gray. In: Tutin TG, Burges NA, Chater AO, Edmondson JR, Heywood VH, Moore DM, Valentine DH, Walters SM, Webb DA (Eds) Flora Europaea, $2^{\text {nd }}$ edn., vol. 1. Cambridge University Press, Cambridge, 260-262.

Chowdhuri PK, Davis PH, Hossain M (1958) Materials for a Flora of Turkey, III.: Ranunculaceae, I. Notes from the Royal Botanic Garden Edinburgh 22(4): 403-425.

Christenhusz MM, Fay MF, Byng JW (2018) The Global Flora Special Edition: GLOVAP Nomenclature Part 1 (Vol. 4). Plant Gateway 4: 1-155.

Davis PH (1965) Flora of Turkey and the East Aegean islands, Vol. 1. Edinburgh University Press, Edinburgh, 567 pp.

Geneva Herbaria Catalogue (2021) Catalogue des herbiers de Genève (CHG), Conservatoire \& Jardin botanique de la Ville de Genève. http:/www.ville-ge.ch/musinfo/bd/cjb/chg/index.php?lang=en [accessed 06 April 2021]

Global Plants JSTOR (2021) Global Plants. http://plants.jstor.org/ [accessed 06.04.2021] Greuter W, Long G (1989) Med-Checklist 4. Conservatoire et Jardin Botaniques de la Ville de Genève, 458 pp. 
Greuter W, Raus T (1989) Med-Checklist Notulae, 15. Willdenowia 19(1): 27-48.

Herbarium Catalogue RBGE (2021) Herbarium Catalogue. https://data.rbge.org.uk/search/ herbarium/ [accessed 06.04.2021]

Holub J, Pouzar Z (1967) A nomenclatural analysis of the generic names of Phanerogams proposed by F. M. Opiz in his Seznam Rostlin Květeny České. Folia Geobotanica et Phytotaxonomica 2(4): 397-428. https://doi.org/10.1007/BF02854724

Huth E (1893) Neue Arten der Gattung Delphinium. Bulletin de l'herbier Boissier 1: 327-336. Huth E (1895) Monographie der Gattung Delphinium. Botanische Jahrbücher für Systematik, Pflanzengeschichte und Pflanzengeographie 20: 322-499. https://doi.org/10.5962/bhl. title. 15558

Iranshahr M (1992) Delphinium L. (Ranunculaceae). In: Rechinger KH (Ed.) Flora Iranica 171. Akademische Druck-und-Verlagsanstalt, Graz, 44-89.

Jabbour F, Renner SS (2011) Consolida and Aconitella are an annual clade of Delphinium (Ranunculaceae) that diversified in the Mediterranean basin and the Irano-Turanian region. Taxon 60(4): 1029-1040. https://doi.org/10.1002/tax.604007

Jabbour F, Renner SS (2012a) A phylogeny of Delphinieae (Ranunculaceae) shows that Aconitum is nested within Delphinium and that Late Miocene transitions to long life cycles in the Himalayas and Southwest China coincide with bursts in diversification. Molecular Phylogenetics and Evolution 62(3): 928-942. https://doi.org/10.1016/j.ympev.2011.12.005

Jabbour F, Renner SS (2012b) Spurs in a spur: Perianth evolution in the Delphinieae (Ranunculaceae). International Journal of Plant Sciences 173(9): 1036-1054. https://doi. org/10.1086/667613

Janchen E (1965) Nomenklatorische Bermerkungen zur Flora Europaea, Vol. I. Feddes Repertorium 72(1): 31-35. https://doi.org/10.1002/fedr.19650720105

Kadereit JW, Albach DC, Ehrendorfer F, Galbany-Casals M, Garcia-Jacas N, Gehrke B, Kadereit G, Kilian N, Klein JT, Koch MA, Kropf M, Oberprieler C, Pirie MD, Ritz CM, Röser M, Spalik K, Susanna A, Weigend M, Welk E, Wesche K, Zhang L-B, Dillenberger MS (2016) Which changes are needed to render all genera of the German flora monophyletic? Willdenowia 46(1): 39-91. https://doi.org/10.3372/wi.46.46105

Kew Herbarium Catalogue (2021) Herbarium Catalogue. https://apps.kew.org/herbcat/gotoHomePage.do [accessed 06.04.2021]

Linnaeus CV (1753) Species plantarum, vol. 1. Laurentii Salvii, Holmiae, 560 pp.

Maire R (1952) In: Quezel P (Ed.) Flore de l'Afrique du Nord (Maroc, Algérie, Tunisie, Tripolitaine, Cyrénaïque et Sahara). Vol. XI. Lechevalier P. Paris, 1-335.

Molero J, Blanché C (1984) A propósito de los géneros Aconitum L. y Consolida (DC.) S.F. Gray en la Península Ibérica. Anales del Jardin Botanico de Madrid 41(1): 211-218.

Mouterde PSJ (1970) Consolida (DC.) S. F. Gray. In: Nouvelle flore du Liban et de la Syrie. Tome II. Texte, Dar El-Machreb Editerus, Beyrouth, 26-27.

Munz PA (1967a) A synopsis of the Asian species of Consolida (Ranunculaceae). Journal of the Arnold Arboretum 48: 159-202.

Munz PA (1967b) A synopsis of African species of Delphinium and Consolida. Journal of the Arnold Arboretum 48: 30-55.

Naturalis BioPortal (2021) BioProtal. https://bioportal.naturalis.nl [accessed 06.04.2021] 
Nevski SA (1937) Ranunculaceae. In: Komarov VL (Ed.) Flora of the U.R.S.S. 7, Izdatel'stvo Akademii Nauk SSSR, Leningrad, 79-143.

Opiz FM (1852) Seznam rostlin květeny české. Praha.

Paris Virtual Herbarium (2021) Paris Virtual Herbarium. https://science.mnhn.fr/institution/ $\mathrm{mnhn} /$ collection/p/item/search [accessed 06.04.2021]

Pfeil BE, Crisp MD (2005) What to do with Hibiscus? A proposed nomenclatural resolution for a large and well-known genus of Malvaceae and comments on paraphyly. Australian Systematic Botany 18(1): 49-60. https://doi.org/10.1071/SB04024

Post GE (1932) Flora of Syria, Palestine and Sinai. $2^{\text {nd }}$ edn. Vol. 1. American Press. Beirut, 639 pp.

Soó R von (1922) Über die mitteleuropäischen Arten und Formen der Gattung Consolida (DC.) S. F. Gray. Oesterreichische Botanische Zeitschrift 71(10-12): 233-246. https:// doi.org/10.1007/BF01662434

Stafleu FA (1967) Taxonomic literature. A selective guide to botanical publications with dates, commentaries and types. International Bureau of Plant Taxonomy and Nomenclature, Utrecht, $556 \mathrm{pp}$.

Strid A, Tan K (2002) Flora Hellenica Vol. 2. A.R.G. Gantner Verlag. Koenigstein, 511 pp.

Sweden's Virtual Herbarium (2021) Sweden's Virtual Herbarium. http://herbarium.emg.umu. se/index.html [accessed 06.04.2021]

Tamura M (1993) Ranunculaceae. In: Kubitzki K, Rohwer JG, Bittrich V (Eds) The Families and Genera of Vascular Plants II. Springer, Berlin, 563-583. https://doi.org/10.1007/9783-662-02899-5_67

Thiébaut J (1936) Flore libano-syrienne. Vol. 1. Imprimerie de l'Institut Français d'Archéologie Orientale. Le Caire, 396 pp.

Thiers B (2018) Index Herbariorum: A global directory of public herbaria and associated staff, New York Botanical Garden's Virtual Herbarium, New York. http://sweetgum.nybg.org/ science/ih/ [accessed 06.04.2021]

University and Jepson Herbaria (2021) University and Jepson Herbaria Specimen Portal. https:// webapps.cspace.berkeley.edu/ucjeps/publicsearch/publicsearch/ [accessed 06.04.2021]

Vahl M (1790) Symbolae botanicae Vol. 1. Excudebant Nicolaus Möller et Filius. Hauniae [København], 81 pp.

Virtual herbaria JACQ (2021) Virtual herbaria JACQ. http://www.jacq.org/\#database [accessed 06.04.2021]

Virtual herbarium Berolinense (2021) Virtual herbarium Berolinense. http://ww2.bgbm.org/ herbarium/ [accessed 06.04.2021]

Wang W, Liu Y, Yu SX, Gao TG, Chen ZD (2013) Gymnaconitum, a new genus of Ranunculaceae endemic to the Qinghai-Tibetan Plateau. Taxon 62(4): 713-722. https://doi. org/10.12705/624.10

Xiang KL, Aytaç Z, Liu Y, Espinosa F, Jabbour F, Byng JW, Zhang CF, Erst AS, Wang W (2017) Recircumscription of Delphinium subg. Delphinium (Ranunculaceae) and implications for its biogeography. Taxon 66(3): 554-566. https://doi.org/10.12705/663.3 